\title{
INFORMATION MODEL OF POST STROKE REHABILITATION CONCEPTION
}

\author{
Rybakova PA ${ }^{1} \otimes$, Koroleva Yul' ${ }^{1}$ Ivanova $\mathrm{GE}^{2}$, Zarubina TV ${ }^{1}$ \\ ${ }_{1}^{1}$ Pirogov Russian National Research Medical University, Moscow, Russia \\ 2 Federal Center of Brain Research and Neurotechnologies of the Federal Medical Biological Agency, Moscow, Russia
}

\begin{abstract}
Currently, the new model of stroke care is actively implemented. There is a number of problems thereby related to digitalization. The study was aimed to work up the information model of the post-stroke rehabilitation at the first stage. The following basic objects of the rehabilitation system information model were identified and described using system analysis and business process modelling, based on studying laws, regulatory and legal acts, clinical guidelines, the "Development of the System of Medical Rehabilitation in Russia" pilot project protocol, and the problem area experts' findings: patient, health information system (HIS) of a healthcare organization, document management. The objects' properties and interaction are discussed, the information model is been constructed, main directions are described.
\end{abstract}

Keywords: information model, healthcare digitalization, medical rehabilitation, acute stroke, electronic document management

Acknowlegements: to Maria A. Bulatova, head of the Department of Patients With Central Nervous System Disorders Medical Rehabilitation of the Federal Center of Brain Research and Neurotechnologies of the Federal Medical Biological Agency, for counceling and strong support.

Author contribution: Rybakova PA — literature analysis, analysis of the results, drawing conclusions, manuscript writing; Koroleva Yul — analysis of the results, drawing coclusions; Ivanova GE — counceling, manuscript writing; Zarubina TV — manuscript writing.

$\bowtie$ Correspondence should be addressed: Polina A. Rybakova

Ostrovitianova, 1, Moscow, 117997; polina240895@rambler.ru

Received: 25.07.2020 Accepted: 22.08.2020 Published online: 31.08.2020

DOI: $10.24075 /$ brsmu.2020.051

\section{КОНЦЕПЦИЯ ИНФОРМАЦИОННОЙ МОДЕЛИ СИСТЕМЫ РЕАБИЛИТАЦИИ БОЛЬНЫХ С ОСТРЫМ НАРУШЕНИЕМ МОЗГОВОГО КРОВООБРАЩЕНИЯ}

\author{
П. А. Рыбакова ${ }^{\otimes}$, Ю. И. Королева ${ }^{1}$, Г. Е. Иванова², Т. В. Зарубина ${ }^{1}$
}

${ }^{1}$ Российский национальный исследовательский медицинский университет имени Н. И. Пирогова, Москва, Россия

2 «Федеральный центр мозга и нейротехнологий» Федерального медико-биологического агентства России, Москва, Россия

\begin{abstract}
В настоящее время происходит активное внедрение новой модели оказания помощи больному с острым нарушением мозгового кровообращения (ОНМК). В связи с этим стоит множество задач, касающихся цифровизации этого процесса. Целью исследования было разработать информационную модель системы реабилитации пациентов с ОНМК на первом этапе оказания помощи. С помощью методов системного анализа, моделирования бизнеспроцессов и на основании изучения нормативно-правовых актов, клинических рекомендаций, протокола пилотного проекта «Развитие медицинской реабилитации в РФ» и результатов работы экспертов проблемной области выделены и проанализированы основные объекты информационной модели системы реабилитации: пациент, МИС МО, документооборот, описаны их свойства и взаимоотношения, построена информационная модель и обозначено направление ее развития.
\end{abstract}

Ключевые слова: информационная модель, цифровизация здравоохранения, медицинская реабилитация, острое нарушение мозгового кровообращения, электронный документооборот

Благодарности: заведующей отделением медицинской реабилитации пациентов с нарушением функции центральной нервной системы ФГБУ «Федеральный центр мозга и нейротехнологий» ФМБА России Марии Анатольевне Булатовой за консультацию и активное участие в работе.

Вклад авторов: П. А. Рыбакова - работа с литературой, анализ результатов, формулировка выводов, оформление рукописи; Ю. И. Королева анализ результатов, формулировка выводов; Г. Е. Иванова - консультация, подготовка рукописи; Т. В. Зарубина — подготовка рукописи.

$\bigotimes$ Для корреспонденции: Полина Алексеевна Рыбакова

ул. Островитянова, д. 1, г. Москва, polina240895@rambler.ru

Статья получена: 25.07.2020 Статья принята к печати: 22.08.2020 Опубликована онлайн: 31.08.2020

DOI: $10.24075 /$ vrgmu.2020.051

One of the ways to improve the quality of post-stroke patients care is the informatization (digitalization) of healthcare system: the complex of measures aimed at providing timely and full information (processed and transformed in certain way) to specialists involved in the diagnosis and treatment process [1].

On January 1, 2019, the "Digital Helthcare Framework" federal project was launched as part of the National project "Healthcare". [2]. The Federal project was focused on the implementation and development of the healthcare information systems and electronic document management in all healthcare organizations and health authorities. The "Development of National Medical Research Centers Network and Introduction of Innovative Medical Technologies" federal project was also partially focused on problems related to healthcare digitalization.
The four vertical integrated systems were designed as part of the project according to the following profiles: oncology, cardiovascular disorders, obstetrics and gynecology (together with neonathology), preventive healthcare. Those should provide continuity of care, patient routing, monitoring of care provision to patients with certain disorders.

The important stage of all four profiles is medical rehabilitation. Until recently, the developments of medical rehabilitation digitalization were localized, whereas the federal level information system development required the comprehensive analysis of the subject area and the step-bystep information model construction.

The study was aimed to analyze the model of post-stroke care through describing the information model basic objects. The future goals and opportunities are mentioned. 


\section{METHODS}

The main documents regulating the existing medical care provision are the Ministry of Health of the Russian Federation orders No. 928H ("On Approval of the Procedure for Medical Care to Patients with Acute Stroke", dated November 15, 2012) and № 1705H ("On the Procedure of Medical Rehabilitation", dated December 29, 2012). To explore the new model of post stroke medical care, the description of the "Development of the System of Medical Rehabilitation in Russia" pilot project (20152016) was used. The Russian and foreign guidelines contain the more detailed description of care measures [3-11]. The WHO documents [12-15] were used to study the International Classification of Functioning, Disability and Health (ICF). The algorithms based on the patient's route and description of the information model objects were designed using the specialized software: MS VISIO 2010 (Microsoft; USA), Axure RP 9 (Axure; USA), draw.io (Voodoo; France); methods of system analysis (problem analysis, system goals and functions setting, modelling), and business process modelling (use case diagram).

\section{RESULTS}

\section{Subject area}

The first stage of the information model constructing is the definition of subject area, i.e. the post-stroke medical rehabilitation description. It includes the patient's condition assessment, rehabilitation goals setting and the formulation of procedure program, drug and non-drug therapy, efficiency of rehabilitation evaluation and prognosis. The updated stroke care model includes three phases [16]. The first phase begins with the patient's admission to the intensive care unit (ICU) of the specialized vascular department and no later than 24 hours from the admission, i. e. during the acute period of the disease $[16,17]$. The patient undergoes the clinical, laboratory and instrumental examinations aimed at identifying the stroke type and subtype, thrombolytic therapy and surgery assignment (if necessary). The intensivist follows the patient's vital parametres and, if necessary, guides him to other specialists. The medical rehabilitation with multidisciplinary rehabilitation team participation is started at the ICU: correction of dysphagia and nutritional deficit, immobilization syndrome prevention (passive or active-passive verticalization, early mobilization). Patient is transferred to neurology department after the stabilization, where the attending neurologist continues the treatment and diagnostic process and organizes the patient's medical rehabilitation with the multidisciplinary team (MDT). The transfer summary report contains the patient's score according to the Rehabilitation Routing Scale (RRS) which is a selection criterion for patient's routing. It's also a selection criteria for clinical and statistical group for medical rehabilitation during all subsequent phases $[18,19]$. So the first phase of rehabilitation includes the medical care in the ICU and neurology department.

Depending on the treatment functional result in vascular department the patient may be routed for further rehabilitation to the second phase in-patient clinic (RSS 4-5), or to the day hospital (RSS 3) and the third phase outpatient clinic (RSS 2). The second and third phases are implemented during the early and late recovery periods and apply to patients with residual symptoms or chronic (non-acute) disease. The patient may carry out the medical rehabilitation third stage activities at home under the guidance of a responsible specialist using telemedicine technology.

The initial medical care phase is the most important and difficult as it requires immediate action. The dynamics of the patient's condition depends on the measures taken at this phase. It is known that the earlier rehabilitation increases medical care effectiveness [20], therefore, the first phase has been chosen as starting point for the information model constructing.

\section{Information model objects}

Currently, the updated model of post-stroke care is actively implemented in Russia [18]. Its algorithm is based on the Federal Centre of Cerebrovascular Pathology and Stroke experts' recommendations (Fig. 1).

The main differences between the new model and the traditional model are the patient-centered care, diagnostics both according to the International Classification of Diseases (ICD) and the International Classification of Functioning, Disability, and Health (ICF), the multidisciplinary team participation. The MDT activity may be presented as a rehabilitation cycle [21]. Representing the new model in this way makes possible to

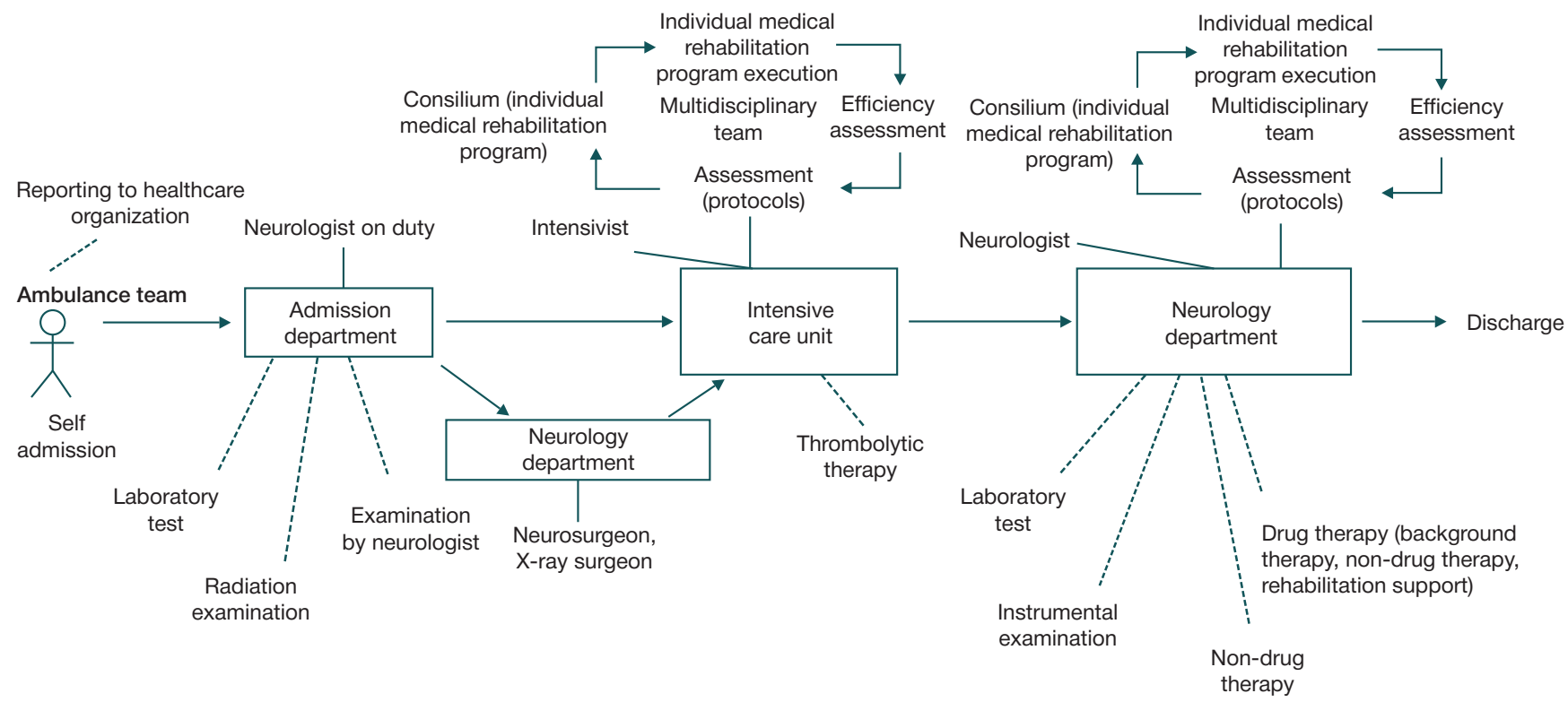

Fig. 1. Post-stroke care algorithm, updated model 


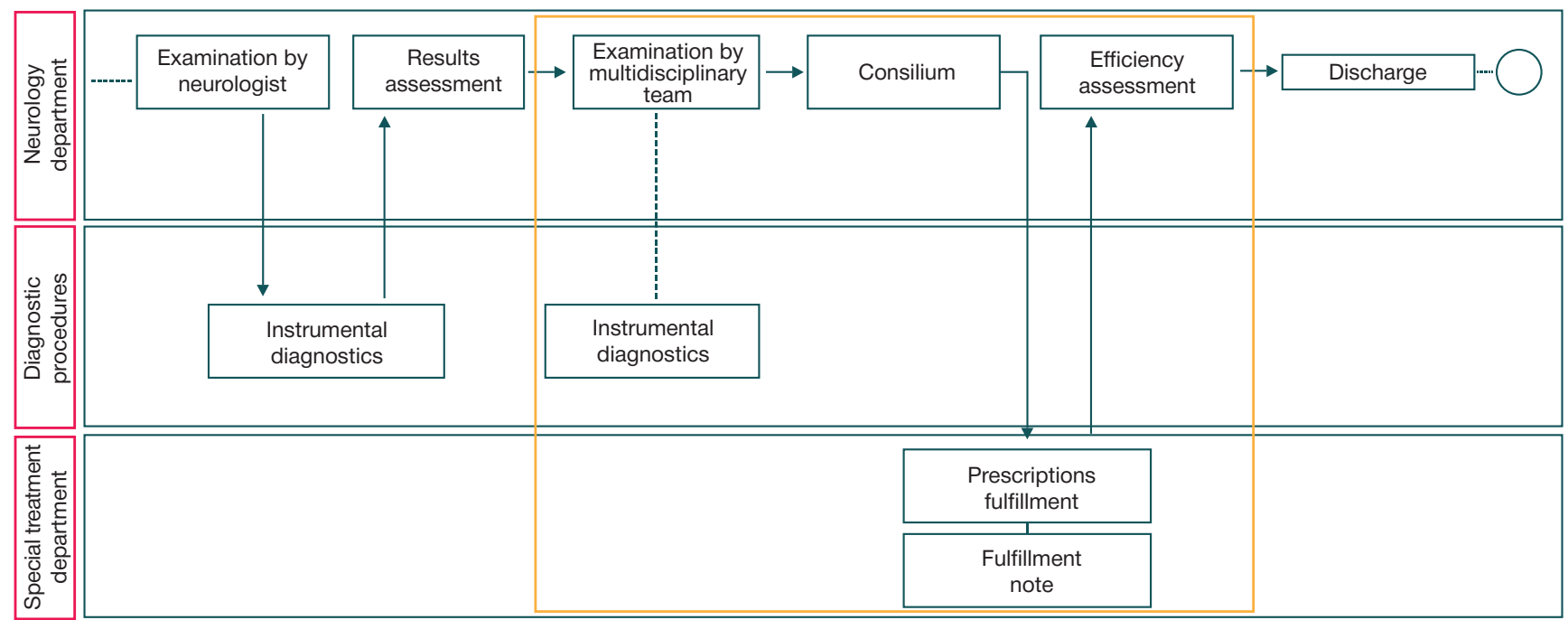

Fig. 2. Fragment of patient's route inside the neurology department

evaluate the time of appearance and actions of each participant of diagnosis and treatment process.

For description and analysis of the object ("Patient") the business process diagram (BPD) was used. It contains details of the patient's route inside the hospital department. The small fragment is presented in Fig. 2. On this diagram the healthcare organization units and the blocks (actions) with the key points of the route are shown as horizontal paths.

After transfer to neurology department the patient is examined by the attending neurologist and all the specialists of the multidisciplinary team, later he undergoes the instrumental and additional laboratory examination with interpretation of the results. The rehabilitation cycle is highlighted with rectangle in Fig. 2.

The other important object of the information model is the health information system (HIS) of a healthcare organization. The system includes multiple integrated subsystems and basic Practice Management Software (PMS). However, the basic HIS does not satisfy the neurology hospital requirements arising from the new model of post acute care. Therefore, it is necessary to expand its functionality. The development of new PMS is required, it concerns the PMS used by specialists of the multidisciplinary team (physical medicine and rehabilitation (PM\&R) physician, intensivist, physical rehabilitation specialist,

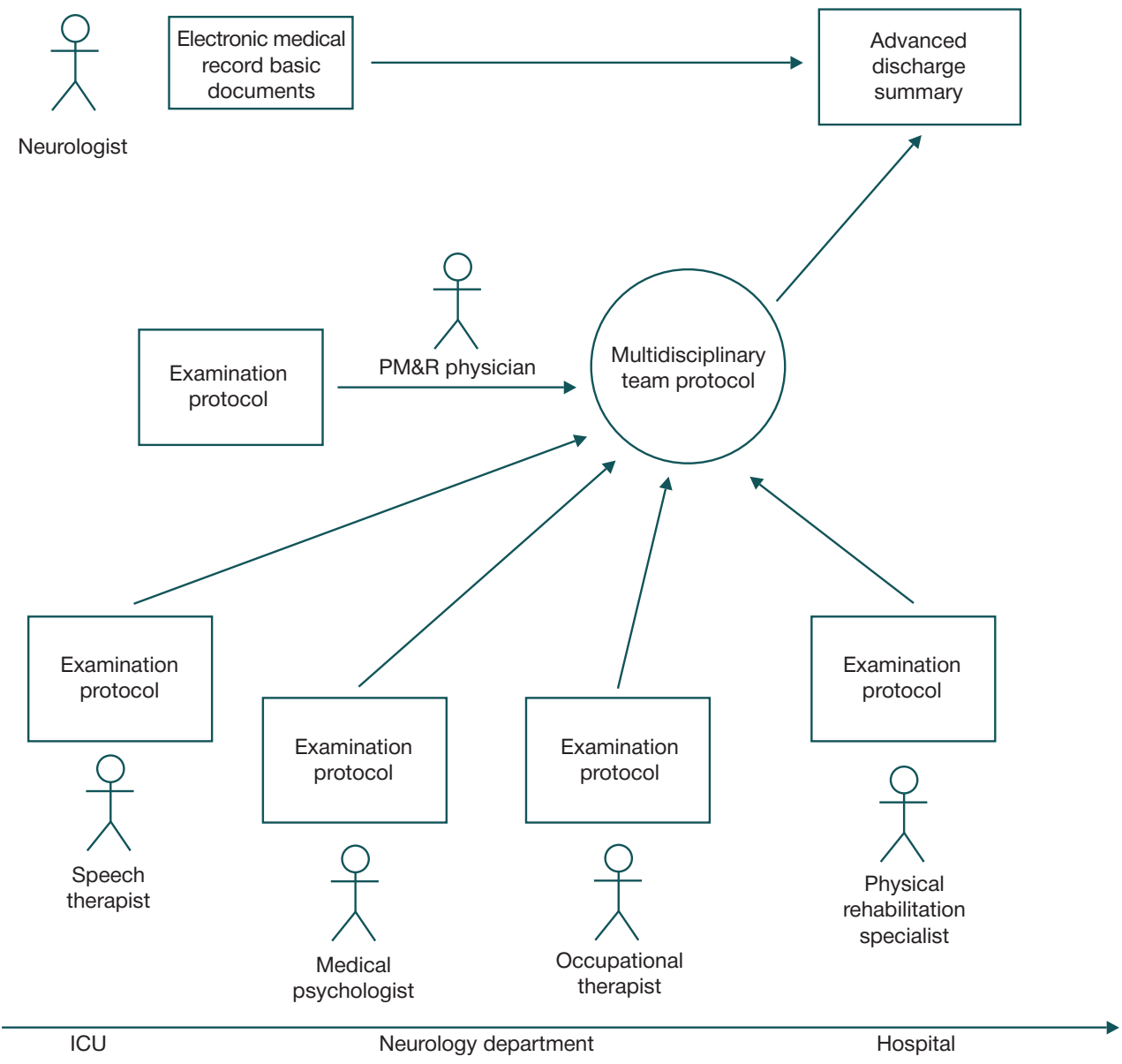

Fig. 3. Medical records registration at the neurology department 


\title{
Multidisciplinary team protocol № 10
}

\author{
08.05.2019
}

Healthcare organization: FCCPS of the Ministry of Health of the Russian Federation

Department: Medical and Social Rehabilitation

Patient: Alexey M. Voskresensky

History №: 35268

Rehabilitation potential:

Rehabilitation Routing Scale Score: 4

Rehabilitation goals:

Long-term: after 3 months the patient will require the outpatient care

Short-term: the patient will be able to walk on his own

Current phase goal: autonomous verticalization

Rehabilitation diagnosis:

Functions and structures

Functions and structures
\begin{tabular}{|l|l|}
\hline \multicolumn{1}{|c|}{ Domain } & \multicolumn{1}{c|}{ Description } \\
\hline b134.2 & Sleep functions \\
\hline b28012.2 & Pain in stomach or abdomen \\
\hline b7301.3 & $\begin{array}{l}\text { Power of muscles } \\
\text { of one limb }\end{array}$ \\
\hline b7401.4 & $\begin{array}{l}\text { Endurance of muscle } \\
\text { groups }\end{array}$ \\
\hline b7603.3 & $\begin{array}{l}\text { Supportive functions } \\
\text { of arm or leg }\end{array}$ \\
\hline b820.4 & Repair functions of the skin \\
\hline s810.0 & Structure of skin \\
\hline
\end{tabular}

Environmental factors

\begin{tabular}{|l|l|}
\hline \multicolumn{1}{|c|}{ Domain } & \multicolumn{1}{c|}{ Description } \\
\hline e260.3 & Air quality \\
\hline e310+3 & Immediate family \\
\hline e540.1 & $\begin{array}{l}\text { Transportation services, } \\
\text { systems and policies }\end{array}$ \\
\hline
\end{tabular}

Limiting factors of the rehabilitation program execution

No

Rehabilitation plan

Activities and Participation
\begin{tabular}{|l|l|}
\hline \multicolumn{1}{|c|}{ Domain } & \multicolumn{1}{|c|}{ Description } \\
\hline d 410.31 & Changing basic body position \\
\hline$d 510.43$ & Washing oneself \\
\hline$d 520.32$ & Caring for body parts \\
\hline d530.31 & Toileting \\
\hline d540.32 & Dressing \\
\hline d550.21 & Eating \\
\hline$d 560.20$ & Drinking \\
\hline
\end{tabular}

Personal factors

\begin{tabular}{|l|l|c|}
\hline \multicolumn{1}{|c|}{ Domain } & \multicolumn{1}{|c|}{ Description } & \\
\hline PF & Acceptance of disease & - \\
\hline PF & $\begin{array}{l}\text { Understanding the need for } \\
\text { rehabilitation }\end{array}$ & + \\
\hline
\end{tabular}

Pиc. 4. Design fragment of the profile document (multidisciplinary team protocol) medical psychologist, speech therapist, occupational therapist [18]), as well as for the PMS used by nursing staff.

\section{Electronic document management}

One of the basic PMS functions is the electronic document management, the electronic medical record and profile documents creation. The following is a fragment of the electronic document management at the first phase of rehabilitation based on the care provision algorithm (Fig. 3).

Each multidisciplinary team specialist creates the first profile document, the examination protocol, after the patient's examination. Once a week or more often the multidisciplinary team specialists hold a consilium, where they discuss and combine the results. After that the physical medicine and rehabilitation (PM\&R) physician makes the rehabilitation diagnosis, sets the long-term and short-term goals of medical rehabilitation, forms the individual rehabilitation plan, defines the executives and sets the rehabilitation schedule. This information is included in the multidisciplinary team general protocol, the second profile document, the fragment is provided in Fig. 4.

The patient's condition assessment (according to ICF, expressed in points) obtained from various MDT specialists is included in the rehabilitation diagnosis.

The third profile document (advanced discharge summary report) is finalized by the attending physician after the first 
Table. Algorithm fragment of NIHSS to ICF translation

\begin{tabular}{|c|c|c|}
\hline & NIHSS & ICF \\
\hline \multirow{7}{*}{1} & Motor leg & $\begin{array}{l}\text { B740 - Muscle endurance functions } \\
\text { B7401 - Endurance of muscle groups }\end{array}$ \\
\hline & $0=$ No drift & 0 B7401.0 \\
\hline & 1 = Drift: leg drifts down but does not hit bed & $1 \mathrm{~B} 7401.1$ \\
\hline & $\begin{array}{l}2 \text { = Leg falls to bed by } 5 \text { seconds but has some effort } \\
\text { against gravity }\end{array}$ & 2 B7401.2 \\
\hline & $3=$ Leg falls immediately & 3 B7401.3 \\
\hline & $4=$ No movement & 4 B7401.4 \\
\hline & $\mathrm{UN}=$ Assessment is impossible & UN B7401.8 \\
\hline \multirow{5}{*}{2} & Dysarthria & $\begin{array}{l}\text { Voice and language functions } \\
\text { B320 - Articulation functions }\end{array}$ \\
\hline & $0=$ Normal & 0 B320.0 \\
\hline & 1 = Mild-to-moderate dysarthria & 1 B320.1- B320.2 \\
\hline & 2 = Severe dysarthria or mute/anarthric patient & 2 B320.3- B320.4 \\
\hline & $\mathrm{UN}=$ Assessment is impossible & UN B320.8 \\
\hline \multirow{6}{*}{3} & Sensory (pinprick and touch) & $\begin{array}{l}\text { Additional sensory functions (b250-279) } \\
\text { B270 - Sensory functions related to temperature and other stimuli }\end{array}$ \\
\hline & $0=$ Normal & 0 B270.0 \\
\hline & $1=$ Partial loss & $1 \mathrm{~B} 270.1$ \\
\hline & $2=$ Severe loss & 2 B270.3 \\
\hline & & B2702 - Sensitivity to pressure \\
\hline & & B2703 - Sensitivity to a noxious stimulus \\
\hline
\end{tabular}

phase of rehabilitation. The document comprises basic clinical data from the electronic medical record, and data from the MDT protocols that describe the activities results and the patient dynamics during treatment.

According to the new post acute care model, the multidisciplinary team specialists assess the patient's state not only using the traditional scales, but also using the ICF domains. Such kind of rehabilitation diagnosis allows the specialists to distinguish between the measures aimed at the patient's survival (diagnosis and treatment process) and the measures aimed at preservation and restoration of vital functions. It is extremely important for the future rehabilitation arrangement.

It should be noted that if patient has undergone surgery for the underlying disease, the additional scales should be used.

\section{Automated rehabilitation diagnosis procedure}

The manual assessment, both using the clinical scales and the required ICF domains, is time-consuming. Therefore, the decision support system element has been developed as an algorithm for converting the NIHSS and other clinical evaluation tools [5] to ICF score. The algorithm fragment is provided in Table.

The algorithm is a matching of the stroke severity scale items scores with the corresponding ICF domains. There is no oneto-one matching in some cases because ICF is a more detailed tool than clinical scales. For example, the item№ 2 of ICF (see Table 1) includes more gradations for articulation disorders, and the NIHSS score 1 may correspond to B320.1 or B320.2 items of ICF. The even more ambiguous situation is observed in the item № 3: the NIHSS Sensory section corresponds to several domains of ICF ("Sensory functions related to stimuli", "Sensitivity to pressure", "Sensitivity to a noxious stimulus"). The algorithm does not offer an unambiguous answer in such "controversial" situations and requires correction by the physician.

\section{DISCUSSION}

The study provides a systematic approach to the post-stroke care informatization. The subject area boundaries had been defined, the information model objects (patient, healthcare organization, HIS of a healthcare organization, electronic document management) and their links and relationships analysis has been performed. Only one study of the discussed topic has been found in literature [22]. It describes the software product in which the patient's clinical data entry and the rehabilitation scales for patient state assessment are partially implemented. The diagnosis is supported using ICF, but the conversion algorithm is not transparent so the algorithm implementation in other systems is impossible.

The approach proposed in this paper may become the ideological and algorithmic basis for the post-stroke patients' management information systems (from hospital to state level).

The obtained results make it possible to determine the further strategy of the rehabilitation system information model development and to define the following priorities:

1) development of technical specifications for the electronic medical record profile documents creation: examination protocol by MDT specialists, general MDT protocol, advanced medical discharge (post-mortem) summary. The development of the standardized electronic medical documents for patient transfer to the second and third phases of rehabilitation and higher HIS levels (regional, federal) is required for the discharge documents and the corresponding implementation guidelines;

2) defining the list of the federal medical references for formalization of the clinical data contained in the profile 
documents: examination protocol by MDT specialist, multidisciplinary team protocol, medical discharge summary;

3) role model development describing the access rights of all process participants of the hospital units;

4) PMS development for specialists taking part in the rehabilitation process: PM\&R physician, physical rehabilitation specialist, neuropsychologist, speech therapist, occupational therapist, massage therapist, physiologist, healthcare assistant;

5) creation of medical decision-support system elements making automated diagnosis according to ICF.

The future development directions are the following: creation of the administrative PMS, analytical and reference modules, patient's account, PMS modules expansion depending on the stroke type and care provided, integration with external systems.

\section{References}

1. Zarubina TV, Kobrinskij BA. Medicinskaja informatika. M. GJeOTAR-Media, 2016; 512 s. Russian.

2. Pasport federal'nogo proekta «Sozdanie edinogo cifrovogo kontura $\vee$ zdravoohranenii na osnove edinoj gosudarstvennoj informacionnoj sistemy $v$ sfere zdravoohranenija (EGISZ)» (utv prezidiumom Soveta pri Prezidente Rossijskoj Federacii po strategicheskomu razvitiju i nacional'nym proektam, protokol \# 16 ot 24 dekabrja 2018 g.). Available from: https://minzdrav.gov.ru/ poleznye-resursy/natsproektzdravoohranenie/tsifra. Russian.

3. Gusev El, Geht AB. Klinicheskie rekomendacii po provedeniju tromboliticheskoj terapii pri ishemicheskom insul'te. M.: GJeOTARMedia, 2015; s. 11-14, 16. Russian.

4. Denisov IN, Kandyba DV, Kuznecova OYu. Diagnostic and tactics of stroke care in general medical practice, including primary and secondary prevention. Clinical guidelines approved on the IV All-Russian Congress of general practitioners (family doctors) of Russian Federation. 2013; 15: 13-24. Russian.

5. Ivanova GE, redaktor. Prakticheskoe primenenie ocenochnyh shkal $v$ medicinskoj reabilitacii. Metodicheskie rekomendacil dlja Pilotnogo proekta «Razvitie sistemy medicinskoj reabilitacii v Rossijskoj Federaciì. 2016; s. 4-7. Russian.

6. Melnikova EV, Bujlova TV, Bodrova RA, Shmonin AA, Maltseva MN, Ivanova GE. International Classification of Functioning, Disability and Health (ICF) in out-patient and in-patient medical rehabilitation: instruction for specialists. Journal of Restorative Medicine. 2017; 6 (82): 1219-28. Russian.

7. Casaubon LK, et al. Canadian stroke best practice recommendations: hyperacute stroke care guidelines, update 2015. International Journal of Stroke. 2016; 10 (6): 924-40.

8. Gutenbrunner C, Ward AB, Chamberlain MA. White book on physical and rehabilitation medicine in Europe. European Journal of Physical and Rehabilitation Medicine. 2006; 42 (4): 295.

9. Hebert D, et al. Canadian stroke best practice recommendations: stroke rehabilitation practice guidelines, update 2015. International Journal of Stroke. 2016; 11 (4): 459-84.

10. Powers WJ, et al. 2018 guidelines for the early management of patients with acute ischemic stroke: a guideline for healthcare professionals from the American Heart Association. American Stroke Association. 2018; 49 (3): 46-99.

11. Steiner $\mathrm{T}$, et al. European Stroke Organisation (ESO) guidelines for the management of spontaneous intracerebral hemorrhage. International Journal of stroke. 2014; 9 (7): 840-55.

12. ICF Research Branch in cooperation with the World Health

\section{CONCLUSION}

Currently, the new post-stroke care model described in the "Development of the System of Medical Rehabilitation in Russia" pilot project protocol is actively implemented both in Russia and foreign countries. According to the model, rehabilitation is carried out by the new diagnosis and treatment process component - the multidisciplinary team using ICF for the patient's condition assessment. This issue should be considered when developing an information system.

The basic information model objects are analyzed, the differences between existing and new models of post-stroke care are identified at this paper. The functions expansion of HIS based on the differences revealed is proposed. The main directions of the rehabilitation system information model are covered: development of profile papers, national references, PMS and HIS additional modules.
Organization Collaborating Centre for the Family of International Classifications (WHO-FIC) in Germany (at DIMDI). Available from: www.icf-research-branch.org.

13. Organisation mondiale de la santé, World Health Organization, World Health Organization Staff. International classification of functioning, disability and health: ICF. World Health Organization, 2001; 299 p.

14. Gimigliano F, Negrini S. The World Health Organization «rehabilitation 2030-a call for action». Eur J Phys Rehabil Med. 2017; 53 (2): 155-168.

15. World Health Organization. WHO global disability action plan 2014-2021: Better health for all people with disability. 2015; 25 p. Available from: https://extranet.who.int/iris/restricted/ handle/10665/199544.

16. Prikaz Ministerstva zdravoohranenija Rossijskoj Federacii \# 1705n ot 29.12.2012 «O porjadke organizacii medicinskoj reabilitacii»». Available from: https://base.garant.ru/70330294/. Russian.

17. Prikaz Ministerstva zdravoohranenija Rossijskoj Fedeacii \# 928n ot 15.11.2012 «Porjadok okazanija medicinskoj pomoshhi bol'nym s ostrymi narushenijami mozgovogo krovoobrashhenija». Available from: https://base.garant.ru/70334856/. Russian.

18. Ivanova GE, Belkin AA, Belyaev AF, Bodrova RA, Bujlova TV, Melnikova EV, et al. Pilot project «Development of medical rehabilitation system in the Russian Federation». General Principles and Protocol. Journal of the Ivanovsky Medical Academy. 2016; (1): 6-11. Russian.

19. Ivanova GE, Melnikova EV, Shmonin AA, Aronov DM, Belkin AA, Belyaev AF, et al. Pilot project «Development of medical rehabilitation system in the Russian Federation». Protocol of the second phase of the project. Scientific notes of PSPbGMU. 2016; (2): 27-34. Russian.

20. Kadomcev DV, Pasechnikova EA, Zanin SA, Kocharjan VYe, Plotnikova W, Vinogradov IO. Thrombolytic therapy in ischemic stroke care. Current status. Current status of science and education. 2016; (4): 40. Russian.

21. Steiner WA, et al. Use of the ICF model as a clinical problemsolving tool in physical therapy and rehabilitation medicine. Physical therapy. Oxford University Press. 2002; 82 (11): 1098-07.

22. Shmonin AA, Nikiforov WV, Maltseva MN, Melnikova EV, Ivanova GE Electronic monitoring of rehabilitation efficacy system in pilot project «Development of medical rehabilitation system in the Russian Federation» - «ICF-reader» program. Journal of the Ivanovsky Medical Academy. 2016; 21 (1): 66-70. Russian. 


\section{Литература}

1. Зарубина Т. В., Кобринский Б. А. Медицинская информатика. М.: ГЭОТАР-Медиа, 2016; 512 с.

2. Паспорт федерального проекта «Создание единого цифрового контура в здравоохранении на основе единой государственной информационной системы в сфере здравоохранения (ЕГИСЗ)» (утВ. президиумом Совета при Президенте Российской Федерации по стратегическому развитию и национальным проектам, протокол № 16 от 24 декабря 2018 г.). Доступно по ссылке: https://minzdrav.gov.ru/ poleznye-resursy/natsproektzdravoohranenie/tsifra.

3. Гусев Е. И., Гехт А. Б. Клинические рекомендации по проведению тромболитической терапии при ишемическом инсульте. М.: ГЭОТАР-Медиа, 2015; с. 11-14, 16.

4. Денисов И. Н., Кандыба Д. В., Кузнецова О. Ю. Диагностика и тактика при инсульте в условиях общей врачебной практики, включая первичную и вторичную профилактику. Клинические рекомендации утверждены на IV Всероссийском съезде врачей общей практики (семейных врачей) Российской Федерации. 2013; 15: 13-24.

5. Иванова Г. Е., редактор. Практическое применение оценочных шкал в медицинской реабилитации. Методические рекомендации для Пилотного проекта «Развитие системы медицинской реабилитации в Российской Федерации». 2016; с. 4-7.

6. Мельникова Е. В., Буйлова Т. В., Бодрова Р. А., Шмонин А. А., Мальцева М. Н., Иванова Г. Е. Использование международной классификации функционирования (МКФ) в амбулаторной и стационарной медицинской реабилитации: инструкция для специалистов. Вестник восстановительной медицины. 2017; 6 (82): 1219-28.

7. Casaubon LK, et al. Canadian stroke best practice recommendations: hyperacute stroke care guidelines, update 2015. International Journal of Stroke. 2016; 10 (6): 924-40.

8. Gutenbrunner C, Ward AB, Chamberlain MA. White book on physical and rehabilitation medicine in Europe. European Journal of Physical and Rehabilitation Medicine. 2006; 42 (4): 295.

9. Hebert D, et al. Canadian stroke best practice recommendations: stroke rehabilitation practice guidelines, update 2015. International Journal of Stroke. 2016; 11 (4): 459-84.

10. Powers WJ, et al. 2018 guidelines for the early management of patients with acute ischemic stroke: a guideline for healthcare professionals from the American Heart Association. American Stroke Association. 2018; 49 (3): 46-99.

11. Steiner $\mathrm{T}$, et al. European Stroke Organisation (ESO) guidelines for the management of spontaneous intracerebral hemorrhage. International Journal of stroke. 2014; 9 (7): 840-55.

12. ICF Research Branch in cooperation with the World Health
Organization Collaborating Centre for the Family of International Classifications (WHO-FIC) in Germany (at DIMDI). Available from: www.icf-research-branch.org.

13. Organisation mondiale de la santé, World Health Organization, World Health Organization Staff. International classification of functioning, disability and health: ICF. World Health Organization, 2001; 299 p.

14. Gimigliano F, Negrini S. The World Health Organization «rehabilitation 2030-a call for action». Eur J Phys Rehabil Med. 2017; 53 (2): 155-168.

15. World Health Organization. WHO global disability action plan 20142021: Better health for all people with disability. 2015; 25 p. Available from: https://extranet.who.int/iris/restricted/handle/10665/199544.

16. Приказ Министерства здравоохранения Российской Федерации № 1705н от 29.12.2012 «О порядке организации медицинской реабилитации». Доступно по ссылке: https:// base.garant.ru/70330294/.

17. Приказ Министерства здравоохранения Российской Федеации №928н от 15.11.2012 «Порядок оказания медицинской помощи больным с острыми нарушениями мозгового кровообращения». Доступно по ссылке: https:// base.garant.ru/70334856/.

18. Иванова Г. Е., Белкин А. А., Беляев А. Ф., Бодрова Р. А., Буйлова Т. В., Мельникова Е. В. и др. Пилотный проект «Развитие системы медицинской реабилитации в Российской Федерации». Общие принципы и протокол. Вестник ИвГМА. 2016; (1): 6-11.

19. Иванова Г. Е., Мельникова Е. В., Шмонин А. А., Аронов Д. М., Белкин А. А., Беляев А. Ф. и др. Пилотный проект «Развитие системы медицинской реабилитации в Российской Федерации». Протокол второй фазы проекта. Ученые записки ПСПбГМУ им. акад. И. П. Павлова. 2016; (2): 27-34.

20. Кадомцев Д. В., Пасечникова Е. А., Занин С. А., Кочарян В. Э., Плотникова В. В., Виноградов И. О. Тромболитическая терапия при ишемическом инсульте. Современное состояние проблемы. Современные проблемы науки и образования. 2016; (4): 40 .

21. Steiner WA, et al. Use of the ICF model as a clinical problemsolving tool in physical therapy and rehabilitation medicine. Physical therapy. Oxford University Press. 2002; 82 (11): 1098-07.

22. Шмонин А. А., Никифоров В. В., Мальцева М. Н., Мельникова Е. В., Иванова Г. Е. Электронная система мониторирования эффективности реабилитации в пилотном проекте «Развитие системы медицинской реабилитации в Российской Федерации» - программа «ICF-reader». Вестник Ивановской медицинской академии. 2016; 21 (1): 66-70. 